\title{
The Renaissance of Transcervical Balloon Catheters for Cervical Ripening and Labour Induction
}

\author{
Renaissance des transzervikalen Ballonkatheters \\ zur Zervixreifung und Geburtseinleitung
}

Authors

Affiliations
W. Rath ${ }^{1}$, S. Kehl ${ }^{2}$

${ }^{1}$ Faculty of Medicine, Gynaecology and Obstetrics, University Hospital RWTH Aachen, Aachen

${ }^{2}$ Department of Obstetrics and Gynaecology, University Hospital Erlangen, Erlangen
Key words
- labour induction
- balloon catheter
- prostaglandins
- effectiveness
safety

\section{Schlüsselwörter \\ - Geburtseinleitung \\ - Ballonkatheter \\ - Prostaglandine \\ - Effektivität \\ - Sicherheit}

Deutsche Version unter: www.thieme-connect.de/ ejournals/gebfra

received 1.6.2015

revised $\quad 7.7 .2015$

accepted 15.7.2015

Bibliography

DOI http://dx.doi.org/

10.1055/s-0035-1558094

Geburtsh Frauenheilk 2015; 75 :

1130-1139 @ Georg Thieme

Verlag KG Stuttgart · New York . ISSN 0016-5751

\section{Correspondence}

Prof. Dr. med. Werner Rath

Gynäkologie und Geburtshilfe

Medizinische Fakultät

Universitätsklinikum

Wendlingweg 2

52074 Aachen

wrath@ukaachen.de

\section{PD Dr. med. Sven Kehl}

Frauenklinik

Universitätsklinikum Erlangen

Universitätsstraße 21-23

91054 Erlangen

sven.keh|@uk-erlangen.de

\section{Abstract \\ $\nabla$}

Due to rising rates of labour induction in industrialised countries, safe and effective methods of induction have once again become a focus of interest and research. Prostaglandins are effective for cervical ripening and induction of uterine contractions. They do, however, cause overstimulation of the uterus in up to $20 \%$ of cases, sometimes causing changes in fetal heart rate. Transcervical balloon catheters provide an alternative to prostaglandins for labour induction and have been used for this purpose for almost 50 years. This induction method has experienced a recent renaissance in clinical practice that is reflected in an annually rising number of publications on its use. Balloon catheters allow gentle ripening of the cervix without causing uterine overstimulation. The two catheters available are the Foley catheter (off-label use) and the double balloon catheter, which is licensed for use in induction of labour. Both are as effective as prostaglandins, and do not increase the risk of infection to mother or child. Catheter induction also requires less monitoring compared to prostaglandins resulting in improved patient satisfaction. Balloon catheters provide a useful and promising option to achieve vaginal delivery despite failed prostaglandin induction. Intravenous oxytocin is nevertheless required in up to $85 \%$ of cases for adequate induction/augmentation of contractions. Balloon catheters, vaginal $\mathrm{PGE}_{2}$ and misoprostol are equally effective in the context of an unripe/unfavourable cervix, the rate of uterine hyperstimulation being significantly lower, and the need for oxytocin significantly higher for catheters. Balloon catheters are increasingly being used in combination or sequentially with oral/vaginal misoprostol, although there is currently inadequate published data on the subject. International guidelines recommend the use of balloon catheters for labour in-

\section{Zusammenfassung}

\section{$\nabla$}

Angesichts steigender Raten in den Industrieländern ist die Frage nach effektiven und sicheren Methoden der Geburtseinleitung wieder in den Fokus des Interesses gelangt. Prostaglandine sind effektiv zur Zervixreifung und Weheninduktion, weisen aber auch in bis zu 20\% der Fälle uterine Überstimulierungen mit und ohne fetale Herzfrequenzveränderungen auf. Eine Alternative ist der seit fast 50 Jahren zur Geburtseinleitung angewandte transzervikale Ballonkatheter, der - wie jährlich steigende Publikationszahlen zeigen eine Renaissance erfahren hat. Ballonkatheter ermöglichen eine schonende Zervixreifung ohne uterine Überstimulierungen. Zur Verfügung stehen der Foley-Katheter (off-label use) und der für die Geburtseinleitung zugelassene Doppelballonkatheter, die so effektiv sind wie Prostaglandine, das Infektionsrisiko für Mutter und Kind nicht erhöhen und bei im Vergleich zu Prostaglandinen geringerem Überwachungsaufwand eine gute Akzeptanz bei den Schwangeren aufweisen. Nach frustraner Geburtseinleitung mit Prostaglandinen sind Ballonkatheter eine vielversprechende Option, noch eine vaginale Geburt zu erreichen. Zur Weheninduktion/-verstärkung ist allerdings in bis zu 85\% der Fälle Oxytocin intravenös erforderlich. Hinsichtlich der Effizienz weisen Ballonkatheter und vaginales $\mathrm{PGE}_{2}$ sowie Misoprostol bei unreifer Zervix keine signifikanten Unterschiede auf, die Rate uteriner Überstimulierungen ist signifikant niedriger, der Oxytocinbedarf signifikant höher. Zunehmend häufiger wird der Ballonkatheter in Kombination oder sequenziell mit oralem/vaginalem Misoprostol eingesetzt, allerdings ist die Datenlage bisher unzureichend. Internationale Leitlinien empfehlen die Anwendung des Ballonkatheters zur Geburtseinleitung bei unreifer Zervix (auch nach vorangegangener Sectio caesarea) als Alternative zu 
duction with an unripe cervix (also following previous caesarean section) as an alternative to prostaglandins, particularly when these are not available or are contraindicated.
Prostaglandinen, insbesondere dann, wenn diese nicht zur Verfügung stehen oder kontraindiziert sind.

\section{Introduction}

In industrialised countries rates of induction of labour have almost doubled in the past 10 years, e.g. the current induction rate in the Netherlands is 33\% [1] and in Germany (2013) 22\% of which $98 \%$ were medical inductions [2].

The advantage of the prostaglandin $\mathrm{E}_{1}$ analogue misoprostol and prostaglandin $\mathrm{E}_{2}\left(\mathrm{PGE}_{2}\right)$ is their efficiency (e.g. rate of vaginal deliveries in 24 hours) when the cervix is unfavourable (Bishop score $[\mathrm{BS}]<6$ ). This is a result of pharmacological synergism between cervix ripening and myometrium stimulating effects [3], the two effects being clinically indistinguishable from one another. The main disadvantage of prostaglandins is a variable rate (3$20 \%$ ) of associated uterine hyperstimulation, which may cause changes in fetal heart rate and thus constitutes a risk factor for fetal hypoxia (e.g. in the context of IUGR with reduced placental reserves) [4].

When the cervix is unfavourable induction of uterine contractions does not accelerate the progress of labour; it worsens fetoplacental perfusion during contractions and patient satisfaction is reduced e.g. through induction of painful contractions. A commentary from the Lancet notes that increasing numbers of clinicians favour the strategy of commencing induction of contractions only once the cervix is ripe [5].

Thus in recent years NO-donors and mechanical induction methods (balloon catheters and cervical dilators such as Lamicel or Dilapan-S) have been the focus of interest (see reviews in [6-8]). NO-donors are currently not recommended in international guidelines due to insufficient literature on their use.

Placement of a transcervical balloon catheter induces cervical ripening without causing significant uterine contractions or systemic side effects in mothers $[7,8]$. Therefore much less monitoring is required during labour compared to prostaglandin induction.

It has been postulated that mechanical stretching by the catheter balloon causes increased release of endogenous prostaglandins e.g. from myometrium and amnionic cells [9], which in turn cause cervical ripening. A recent prospective study found that cervical ripening was triggered by a local inflammatory reaction; significantly raised levels of interleukin-6 and interleukin-8, metalloproteinase-8, hyaluronic acid synthetase and NO synthetase were found on immunohistochemistry of cervical tissue following balloon insertion [10].

Balloon catheters have been used for labour induction as far back as the 1890s. Embrey and Mollison rediscovered the method in 1967 using it in combination with extraamniotic prostaglandins (see review in [11]). Since then numerous studies have been performed worldwide, mostly using the Foley catheter.

Developed by Atad in 1990, the double balloon catheter was expected to provide improved results. It was hoped that the simultaneous application of pressure to the inner and outer cervical openings would cause even more effective cervical ripening compared to the single balloon catheter. The double balloon catheter is now commercially available and licensed for cervical ripening (labour induction) and may be in place for up to 12 hours; prostaglandins, current or planned, and low-lying placenta/placenta praevia are some of the contraindications to its use. Important to note is that according to the manufacturer's warning, the safety and effectiveness of the double balloon catheter for cervical ripening has not been shown in the context of previous isthmus-transverse caesarean section and its use is therefore contraindicated after previous caesarean section. This problem is the subject of a subsequent, independent publication of the authors and will therefore not be discussed further here.

Expulsion of the double balloon catheter usually occurs at a cervical dilation of about $4 \mathrm{~cm}$.

In recent years there has been a veritable renaissance of balloon catheter use for labour induction with almost two thirds of the literature on the subject from the past 15 years having been published in the last 5 years. Combinations of medical and mechanical methods have been studied in particular. This review article aims to provide an overview of the current evidence on labour induction using balloon catheters.

\section{Implementation in Clinical Practice \\ $\nabla$}

\section{Comparison of Foley catheter}

vs. double balloon catheter

We identified 4 randomised trials comparing Foley and double balloon catheters for labour induction [12-15]. The results are somewhat contradictory ( Table 1). In 3 studies the Foley catheter was shown to have significant advantages [12,14,15], in two other studies the double balloon catheter was more effective [13, 16]. Taking all available data into account, no significant difference between the two catheters has been clearly demonstrated. All studies note the better cost-effectiveness of the Foley catheter; the double balloon catheter has the major advantage of being licensed for labour induction.

\section{Balloon filling}

The filling volume of the double balloon is up to $80 \mathrm{ml}$. Various trials have studied the effectiveness of different filling volumes when using the Foley catheter. Three randomised studies compared a filling volume of $30 \mathrm{ml}$ with $60 \mathrm{ml} \mathrm{[17]} \mathrm{and} 80 \mathrm{ml} \mathrm{[18,}$ 19] ( Table 2). All three studies were included in a recently published systematic review and meta-analysis by Berndl et al. [20]. Although there was no significant difference in caesarean section rate (RR 0.82; 95\% CI 0.48-1.41) the likelihood of a favourable cervix (not uniformly defined) was greater with larger filling volumes (RR 1.72; 95\% CI 1.46-2.04), and the rate of women not delivered within 24 hours was significantly reduced (RR 0.70; 95\% CI 0.54-0.90). Another randomised study examined whether traction to the Foley catheter influences rate of cervical dilatation (filling volume $30 \mathrm{ml}$, weighted traction using a $1000 \mathrm{ml}$ fluidfilled bag; $n=60$ ). Time to cervical opening was significantly reduced in the weighted traction group (by approx. 3 hours) without an increased rate of pain perception following balloon insertion [21]. In the above mentioned study by Kashanian et al. [19], 500-ml-weighted traction had no additional effect ( $\bullet$ Table 2 ).

\section{Premature rupture of membranes}

Balloon catheters are not used or are removed when membranes rupture prematurely; alternatively the catheter remains in situ 
Table 1 Randomised controlled trials of Foley catheter vs. double balloon catheter.

\begin{tabular}{|c|c|c|c|c|c|c|}
\hline $\begin{array}{l}\text { Lead } \\
\text { author }\end{array}$ & Year & n & Foley catheter (F) & $\begin{array}{l}\text { Double balloon } \\
\text { catheter (DB) }\end{array}$ & Significant findings & \\
\hline \multirow[t]{2}{*}{$\begin{array}{l}\text { Pennell } \\
\text { CE [12] }\end{array}$} & 2009 & $\begin{array}{l}320 \\
\text { (nullipa- } \\
\text { rae) }\end{array}$ & $\begin{array}{l}\text { Filling vol.: } 30 \mathrm{ml} \\
\text { in situ time } 12 \mathrm{~h}\end{array}$ & $\begin{array}{l}80 \mathrm{ml} \\
12 \mathrm{~h} \text { or } \mathrm{PGE}_{2} \text { vaginal gel }\end{array}$ & $\begin{array}{l}\text { Induction to delivery time (h, median) } \\
\mathrm{F}: 23.2 \\
\mathrm{DB}: 24.5 \\
\mathrm{PGE}_{2}: 23.8\end{array}$ & $p=0.043$ \\
\hline & & & & & $\begin{array}{l}\text { Perceived as painful (pain score } \geq 4 \text { ) }(\%) \\
\text { F: } 36 \\
\text { DB: } 55 \\
\text { PGE }_{2}: 63\end{array}$ & $p<0.001$ \\
\hline \multirow[t]{3}{*}{ Solt I [13] } & $2009^{*}$ & 200 & $\mathrm{n} / \mathrm{a}$ & $\mathrm{n} / \mathrm{a}$ & $\begin{array}{l}\text { Caesarean section rate in nulliparae (\%) } \\
\text { F: } 40 \\
\text { DB: } 20\end{array}$ & $p=0.02$ \\
\hline & & & & & $\begin{array}{l}\text { Balloon removal to delivery time (nulliparae) (h) } \\
\text { F: } 22.6 \\
\text { DB: } 14.6\end{array}$ & $p=0.05$ \\
\hline & & & & & $\begin{array}{l}\text { Bishop score after balloon removal (nulliparae) } \\
\text { F: } 3.4 \pm 2.0 \\
\text { DB: } 4.4 \pm 1.9\end{array}$ & $p=0.02$ \\
\hline $\begin{array}{l}\text { Salim R } \\
\text { [14] }\end{array}$ & 2011 & 293 & $\begin{array}{l}\text { Filling vol.: } 60 \mathrm{ml} \\
\text { in situ time } 12 \mathrm{~h}\end{array}$ & $\begin{array}{l}80 \mathrm{ml} \\
12 \mathrm{~h}\end{array}$ & $\begin{array}{l}\text { Rate of vacuum extraction or c-section (\%) } \\
\text { F: } 14.4 \\
\text { DB: } 25.7\end{array}$ & $p=0.02$ \\
\hline \multirow[t]{2}{*}{$\begin{array}{l}\text { Mei-Dan } \\
\text { E[15] }\end{array}$} & 2012 & 188 & $\begin{array}{l}\text { Filling vol.: } 30 \mathrm{ml} \\
\text { in situ time } 12 \mathrm{~h} \\
+ \text { extraamniotic } \\
\mathrm{NaCl} 50 \mathrm{ml} / \mathrm{h}\end{array}$ & $\begin{array}{l}80 \mathrm{ml} \\
12 \mathrm{~h}\end{array}$ & $\begin{array}{l}\text { Balloon insertion to expulsion time (h) } \\
\text { F: } 6.9 \pm 4.2 \\
\text { DB: } 10.1 \pm 4.7\end{array}$ & $p=0.001$ \\
\hline & & & & & $\begin{array}{l}\text { Induction to delivery time (h) } \\
\text { F: } 19.6 \pm 11.4 \\
\text { DB: } 23.4 \pm 15.5\end{array}$ & $p=0.03$ \\
\hline \multirow[t]{2}{*}{$\begin{array}{l}\text { Mei-Dan } \\
\text { E[16] }\end{array}$} & 2014 & 186 & $\begin{array}{l}\text { Filling vol.: } 30 \mathrm{ml} \\
+ \text { extraamniotic } \\
\mathrm{NaCl} 50 \mathrm{ml} / \mathrm{h} \\
\text { in situ time } 12 \mathrm{~h}\end{array}$ & $\begin{array}{l}80 \mathrm{ml} \\
+ \text { extraamniotic } \mathrm{NaCl} \\
50 \mathrm{ml} / \mathrm{h} \\
12 \mathrm{~h}\end{array}$ & $\begin{array}{l}\text { Caesarean section rate }(\%) \\
\text { F: } 20 \\
\text { DB: } 8.3\end{array}$ & $p=0.05$ \\
\hline & & & & & $\begin{array}{l}\text { Induction to delivery time (h, median) } \\
\text { F: } 15.8 \\
\text { DB: } 14.3\end{array}$ & $p=0.04$ \\
\hline
\end{tabular}

* published as abstract only

Table 2 Randomised controlled trials comparing various filling volumes.

\begin{tabular}{|c|c|c|c|c|c|c|}
\hline $\begin{array}{l}\text { Lead } \\
\text { author }\end{array}$ & Year & n & $\begin{array}{l}\text { Standard filling } \\
\text { volume (SF) }\end{array}$ & $\begin{array}{l}\text { Greater filling } \\
\text { volume (GF) }\end{array}$ & Significant results & \\
\hline \multirow[t]{3}{*}{$\begin{array}{l}\text { Levy R } \\
{[18]}\end{array}$} & 2004 & 203 & $30 \mathrm{ml}$ & $80 \mathrm{ml}$ & $\begin{array}{l}\text { Cervical dilatation } \geq 3 \mathrm{~cm} \text { to cervical ripening (\%) } \\
\text { SF: } 52.4 \\
\text { GF: } 76.0\end{array}$ & $\mathrm{p}<0.001$ \\
\hline & & & & & $\begin{array}{l}\text { Vaginal delivery rate in } 24 \mathrm{~h} \text { in nullipara }(\%) \\
\text { SF: } 49.0 \\
\text { GF: } 71.4\end{array}$ & $p<0.05$ \\
\hline & & & & & $\begin{array}{l}\text { Oxytocin augmentation in nullipara (\%) } \\
\text { SF: } 90.4 \\
\text { GF: } 69.3\end{array}$ & $p<0.05$ \\
\hline \multirow[t]{2}{*}{$\begin{array}{l}\text { Kashani- } \\
\text { an M [19] }\end{array}$} & 2009 & 270 & $30 \mathrm{ml}$ with traction & $80 \mathrm{ml}$ without traction & $\begin{array}{l}\text { Bishop score } \geq 9(\%) \\
\text { SF: } 38.9 \\
\text { GF: } 83.3\end{array}$ & $p<0.001$ \\
\hline & & & & & $\begin{array}{l}\text { Vaginal deliveries (\%) } \\
\text { SF: } 83.3 \\
\text { GF: } 90.0\end{array}$ & $\mathrm{p}<0.001$ \\
\hline \multirow[t]{2}{*}{$\begin{array}{l}\text { Delaney } \\
\text { S [17] }\end{array}$} & 2010 & 192 & $30 \mathrm{ml}$ & $60 \mathrm{ml}$ & $\begin{array}{l}\text { Vaginal delivery rate in } 24 \mathrm{~h}(\%) \\
\text { SF: } 14.0 \\
\text { GF: } 26.0\end{array}$ & $p<0.04$ \\
\hline & & & & & $\begin{array}{l}\text { Cervical dilatation at balloon expulsion } \\
\text { SF: } 3 \mathrm{~cm} \\
\text { GF: } 4 \mathrm{~cm}\end{array}$ & $p<0.01$ \\
\hline
\end{tabular}


Table 3 Labour induction: Foley catheter vs. vaginal PGE 2 gel: PROBAAT-study (randomised, controlled, multicentre, $n=824$ ) [28].

\begin{tabular}{|c|c|c|c|}
\hline Criteria (selected) & $\begin{array}{l}0.5 \mathrm{mg} \mathrm{PGE} \mathrm{P}_{2} \text { vaginal gel } \\
(\mathrm{n}=408)\end{array}$ & $\begin{array}{l}\text { Foley catheter } \\
(n=412)\end{array}$ & p-value \\
\hline Caesarean section rate (\%) & 20 & 23 & NS \\
\hline Caesarean due to failure to progress in the 1st stage of labour (\%) & 8 & 12 & 0.021 \\
\hline Operative delivery due to fetal distress (\%) & 18 & 12 & 0.0218 \\
\hline Induction to delivery time (median, h) & 18 & 29 & $<0.0001$ \\
\hline Oxytocin augmentation (\%) & 59 & 86 & $<0.0001$ \\
\hline Uterine hyperstimulation (tachysystole/contractions lasting > $3 \mathrm{~min}$ ) (\%) & 3 & 2 & NS \\
\hline Uterine rupture/perforation ( $\mathrm{n}$ ) & 2 & 0 & NS \\
\hline Suspected maternal infection (intrapartum fever and commencement of antibiotics) (\%) & 3 & 1 & 0.035 \\
\hline Neonatal admission (\%) & 20 & 12 & 0.0019 \\
\hline
\end{tabular}

NS = not significant

for a maximum of 12 hours during the 1 st stage of labour [8]. The Foley catheter (filling volume $30 \mathrm{ml}$ ) was compared to vaginal misoprostol ( $25 \mu \mathrm{g}$ 4-hourly or $50 \mu \mathrm{g}$ 6-hourly) in a retrospective observational study of 122 pregnant women with premature rupture of membranes $\geq 36$ SSW [22]. The median induction to delivery time was significantly shorter for the Foley catheter group (736 vs. $1354 \mathrm{~min}$ ) though use of oxytocin for augmentation of labour was significantly higher; caesarean section rates were comparable (36.3 vs. 39.4\%). The incidence of chorioamnionitis (defined as intrapartum fever with need for antibiotics or anatomical/pathological evidence of chorioamnionitis) was significantly lower in Foley catheter patients (11.5\%) compared to those receiving vaginal misoprostol (27.3\%); notably, it is well known that frequent vaginal manipulations increase the risk of infection.

A recent retrospective cohort study of 129 women with premature rupture of membranes close to term showed the rate of chorioamnionitis (not defined by the authors) non-significantly increased in Foley catheter patients compared to those with intravenous oxytocin/vaginal misoprostol (30.2 vs. $16.3 \%$ respectively, $\mathrm{p}=0.066$ ); the multivariate regression analysis found nulliparity and measurement of intrauterine pressure (both twice as common in the Foley catheter group) to be independent risk factors for chorioamnionitis, though method of induction was not [23]. A multicentre randomised trial of the use of Foley catheter in the context of premature rupture of membranes near term (FOLCROM trial) is currently underway [24].

\section{Risk of infection}

Whether the placement of a "foreign body" into the uterus increases the risk of infection or not is currently a topic of debate, the evidence being astoundingly sparse and contradictory. Recent review articles either do not mention infection risk at all [6, 7] or quote the two meta-analyses noted below. According to available literature there has not been a single reported case of serious infection or sepsis associated with balloon catheters used for labour induction, though it should be noted that studies have been conducted almost exclusively on women with intact membranes [8].

The meta-analysis by Heinemann et al. 2008 [25] that included 30 randomised controlled trials $(n=4468)$ comparing the Foley catheter to medical methods of induction found a significantly increased rate of maternal infections ( 7.6 vs. 5.0\%, pooled OR: 1.50; 95\% CI 1.07-2.09). Infection was defined as fever, endomyometritis or chorioamnionitis. The rate of chorioamnionitis was significantly raised (7.6 vs. 3.7\%, pooled OR: 2.05 ; $95 \%$ CI $1.22-$
3.44), rates of endomyometritis non-significantly raised (5.1 vs. $3.2 \%$, pooled OR: $1.42 ; 95 \%$ CI $0.74-2.97$ ). There are no randomised studies of prophylactic antibiotic use in this context to date. The 2012 Cochrane review (33 trials using the Foley catheter) concluded that in view of the limited number of trials and differing criteria for infections, there is no evidence that balloon catheters increase infection risk. The authors do warn though, that the results should be interpreted with caution [26].

A detailed analysis of the infectious morbidity within the trials included was not performed in the Cochrane review.

Interestingly, a recent multicentre study from the Netherlands showed that placement of an intrauterine pressure catheter did not increase infection risk up to 3 weeks postpartum when compared to external tocometry ( 8.8 vs. $10.4 \%$ respectively [27]). Another large Dutch multicentre trial $(n=824)$ compared the Foley catheter to vaginal $\mathrm{PGE}_{2}$ gel [28]. Suspected intrapartum infection (defined as body temperature $\geq 38^{\circ} \mathrm{C}$ and commencement of broad spectrum antibiotics) was diagnosed in $1 \%$ of patients with Foley catheter and $3 \%$ with vaginal $\mathrm{PGE}_{2}(\mathrm{p}=0.035)$, and the rate of neonatal admission was significantly higher following $\mathrm{PGE}_{2}$ (20 vs. $12 \%, \mathrm{p}=0.002$, ○ Table 3 ).

In conclusion it can be assumed that the placement of a balloon catheter is not associated with increased infection risk, particularly when compared to repeated vaginal application of prostaglandins.

\section{Failed induction with prostaglandin/misoprostol}

Notwithstanding differing definitions of the term "failed induction" $[26,29,30]$, balloon catheters are a promising option in this setting, though research evidence is insufficient. 75\% of women delivered vaginally when a Foley catheter was used following failed induction with $3 \mathrm{mg} \mathrm{PGE}_{2}$ vaginal tablet (no evidence of labour onset after 2-3 applications) [31], and after failure of $50 \mu \mathrm{g}$ vaginal misoprostol - applied 6-hourly to the unripe cervix (no evidence of labour onset after 24 hours) - 93 of 112 women (83\%) delivered vaginally [32].

In our view, women who have failed induction with prostaglandins and who still wish to deliver vaginally should be offered further induction with a balloon catheter. The decision should be made together with the patient and on an individual basis, considering all potential risks and benefits.

\section{Patient satisfaction}

Patient satisfaction with balloon catheters vs. medical induction is not addressed in existing reviews/meta-analyses [7,8,26,33, 34] or current guidelines. Only Penell et al. 2009 [12], whose pre- 
viously mentioned randomised study was included in the 2012 Cochrane review [22], state finding no significant difference in overall satisfaction among women induced with Foley catheter, double balloon catheter or $\mathrm{PGE}_{2}$ vaginal gel.

A very recent comparative study of double balloon catheter and $10 \mathrm{mg} \mathrm{PGE} 2$ vaginal insert in oligohydramnios at term has come to a similar conclusion: Although balloon catheter placement was significantly more unpleasant than the vaginal insert, no significant difference was found in patient satisfaction between the two methods [35].

Patient satisfaction was the focus of a prospective, randomised trial in which oral misoprostol alone was compared to a combination of oral misoprostol plus double balloon catheter for labour induction in 122 women [36]. Findings were as follows: There was no significant difference in patient satisfaction between the two methods; women were not bothered by the insertion of the double balloon catheter or its presence subsequently; significantly more women in the combination group would choose the same method of induction in a subsequent pregnancy or would recommend it to others; the birth experience, assessed using a standardized questionnaire on postpartum mental state which provides a total score for birth experience (Salmon's item list), was positive in both groups but significantly better in the combination group compared to misoprostol alone.

A pre-publication study from Israel [37] found that patient satisfaction (calculated using a 10 point scale) was significantly lower in obese pregnant women (body mass index $>30$ ) compared to non-obese women (BMI $\leq 30,5.95 \pm 3.14$ vs. $7.85 \pm 2.7 ; \mathrm{p}=0.009$ ). It has been recognised that this important criterion of labour induction with balloon catheters compared to other methods needs further research and two current randomised studies (oral misoprostol vs. Foley catheter) in the Netherlands [38] and the USA [39] address the issue.

Of relevance to clinical practice is the observation that the insertion of a Foley catheter using a speculum is significantly more often experienced as painful by patients (visual analogue scale) compared to digital insertion. However, once again, overall satisfaction with the method was not affected [40].

\section{Balloon Catheter vs. Prostaglandin $E_{2}$} $\nabla$

Balloon catheters alone only lead to effective uterine contractions during cervical ripening $15-33 \%$ of the time; in $67-85 \%$ of cases intravenous oxytocin (mostly commenced concurrently with balloon insertion or after balloon expulsion using various dosing schedules) is necessary for augmentation of labour [41,42].

Previous studies/meta-analyses comparing balloon catheters and prostaglandins for labour induction have focussed almost exclusively on differing filling volumes using the Foley catheter.

The most recent Cochrane review, which includes 23 randomised studies, provides an overview of published data on balloon catheter vs. prostaglandins ( $\mathrm{PGE}_{2}$ and misoprostol) [26]. The results ( Table 4) are in general agreement with a meta-analysis by Vaknin et al. from 2010 [43] as well as two subsequently published randomised controlled trials $[12,44]$, so that in 2011 Henderson et al. are able to conclude that in nulliparae and multiparae with unfavourable cervix, transcervical balloon catheter is preferable to $\mathrm{PGE}_{2}$ with respect to safety, cost, patient satisfaction and length of labour [45].
Table 4 Labour induction: balloon catheter vs. prostaglandins (prostaglandin $E_{2}$, misoprostol). Results of 2012 Cochrane review [26].

tendency to increased rate of women not delivered within $24 \mathrm{~h}$ : 48 vs. $38 \%$ (RR $1.26 ; 95 \%$ Cl $0.94-1.68$ )

- no significant difference in caesarean section rate:

27 vs. $25 \%$ (RR $1.01 ; 95 \% \mathrm{Cl} 0.90-1.13$ )

- no significant difference in cervical ripening (cervix unfavourable after $12-24$ h): 37 vs. $39 \%$ (RR 0.96; $95 \%$ Cl $0.70-1.34$ )

- significantly higher rate of need for augmentation of labour with oxytocin: 75 vs. $80 \%$ (RR $1.51 ; 95 \%$ Cl 1.15-1.97)

- significantly lower rate of uterine hyperstimulation with fetal heart rate changes: 0.4 vs. $3 \%$ (RR $0.19 ; 95 \% \mathrm{Cl} 0.08-0.43$ )

Jozwiak M et al. Cochrane Database Syst Rev 2012; 3: CD001233.

Comparable results in: Vaknin Z et al. AJOG 2010 (meta-analysis [43])

\section{Balloon catheter vs. $\mathrm{PGE}_{2}$ vaginal gel}

The largest randomised, controlled trial to date on the subject (PROBAAT-trial) compared the Foley catheter (filling volume $30 \mathrm{ml}+$ amniotomy and i. v. oxytocin on catheter expulsion or BS $>6$ dependant on uterine activity) to $\mathrm{PGE}_{2}$ vaginal gel ( $1 \mathrm{mg}$ initially, repeated after $6 \mathrm{~h}$ then twice daily, initial dose in nulliparae $2 \mathrm{mg}$ ) in 824 women with unfavourable cervix (BS <6) [28]. Results are shown in $\bigcirc$ Table 3 . The authors of a meta-analysis that takes these results into account as well as the results of two other recent randomised trials using $\mathrm{PGE}_{2}$ vaginal gel in controls [12, 44 ] conclude the following:

- No significant difference in caesarean section rate, however with Foley catheter caesarean more often indicated because of failure to progress; lower rates due to fetal distress.

- Longer induction to birth times for Foley catheter compared to $\mathrm{PGE}_{2}$, possibly due to delayed commencement of oxytocin and/ or amniotomy only after catheter expulsion (e.g. at night) (also compare with [7]).

- With Foley catheter, significantly lower rate of uterine hyperstimulation in the meta-analysis (RR $0.44 ; 95 \%$ CI $0.21-0.9$ ) but not in the PROBAAT-trial ( 2 vs. $3 \%, \mathrm{p}=0.36$ ); no significant effect on neonatal outcome (5-minute Apgar score, umbilical cord $\mathrm{pH}$ ).

The unanimously stated advantages of balloon catheters compared to $\mathrm{PGE}_{2}$ in clinical practice are less need for monitoring during the first stage of labour, simple storage at room temperature and lower cost $[6,7,24]$.

The latest cost-effectiveness analysis on the PROBAAT-trial data [46] that included costs of labour ward admission, those for additional medication and regional anaesthesia, for the induction method itself and for the delivery showed no significant differences in cost between Foley catheter and vaginal $\mathrm{PGE}_{2}$ for induction with unfavourable cervix.

\section{Balloon catheter vs. $\mathrm{PGE}_{2}$ vaginal insert}

Four randomised trials together including 824 patients have compared the Foley [47] and double balloon catheters [41,42, 48] with $10 \mathrm{mg} \mathrm{PGE} 2$ vaginal insert (insertion time up to $24 \mathrm{~h}$ ) for labour induction with unfavourable cervix (Bishop score $\leq 6$ ) ( Table 5). Cromi et al. 2011 [47] left the Foley catheter in situ for either 12 or 24 hours and on catheter expulsion gave oxytocin intravenously. There were no significant differences between the methods for caesarean section rate or effectiveness of cervical ripening after 12 and 24 hours; the rate of uterine hyperstimulation was however significantly lower with Foley catheter (0 vs. $6.1 \%$ ). Rate of vaginal deliveries in 24 hours was only $21 \%$ for Fo- 
Table 5 Randomised, controlled trials: balloon catheter vs. $\mathrm{PGE}_{2}$ vaginal insert.

\begin{tabular}{|c|c|c|c|c|c|c|}
\hline $\begin{array}{l}\text { Lead } \\
\text { author }\end{array}$ & Year & $\mathbf{n}$ & Balloon catheter & $\begin{array}{l}10 \mathrm{mg} \mathrm{PGE} \\
\text { vaginal insert }\end{array}$ & Significant findings & \\
\hline \multirow[t]{2}{*}{$\begin{array}{l}\text { Cromi A } \\
{[47]}\end{array}$} & 2011 & 397 & $\begin{array}{l}\text { Foley }(\mathrm{F}) \\
\text { filling volume: } 50 \mathrm{ml} \\
\text { in situ time: } \\
\text { A: } 24 \mathrm{~h} \\
\text { B: } 12 \mathrm{~h}\end{array}$ & $24 \mathrm{~h}$ & 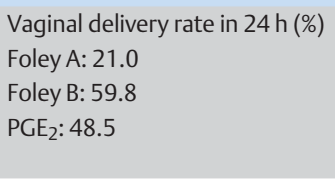 & $p=0.0001$ \\
\hline & & & & & $\begin{array}{l}\text { Oxytocin augmentation (\%) } \\
\text { Foley } \mathrm{A}: 81.2 \\
\text { Foley B: } 81.8 \\
\text { PGE }: 53.8\end{array}$ & $p=0.05$ \\
\hline \multirow[t]{3}{*}{$\begin{array}{l}\text { Cromi A } \\
{[41]}\end{array}$} & 2012 & 208 & $\begin{array}{l}\text { Double balloon (DB) } \\
\text { filling volume: } 80 \mathrm{ml} \\
\text { in situ time: } 12 \mathrm{~h}\end{array}$ & $24 \mathrm{~h}$ & $\begin{array}{l}\text { Vaginal delivery rate in } 24 \mathrm{~h}(\%) \\
\mathrm{DB}: 68.6 \\
\mathrm{PGE}_{2}: 49.5\end{array}$ & $p=0.007$ \\
\hline & & & & & $\begin{array}{l}\text { Oxytocin augmentation (\%) } \\
\text { DB: } 85.7 \\
\text { PGE }_{2}: 54.4\end{array}$ & $p<0.0001$ \\
\hline & & & & & $\begin{array}{l}\text { Uterine hyperstimulation (\%) } \\
\text { DB: } 0 \\
\text { PGE }: 9.7\end{array}$ & $p<0.0007$ \\
\hline \multirow[t]{2}{*}{ Du C [42] } & 2014 & 155 & $\begin{array}{l}\text { Double balloon (DB) } \\
\text { filling volume: } 80 \mathrm{ml} \\
\text { in situ time: } 12 \mathrm{~h}\end{array}$ & $24 \mathrm{~h}$ & $\begin{array}{l}\text { Oxytocin augmentation (\%) } \\
\text { DB: } 75 \\
\text { PGE }: 53.2\end{array}$ & $p<0.001$ \\
\hline & & & & & $\begin{array}{l}\text { Uterine hyperstimulation (\%) } \\
\text { DB: } 0 \\
\text { PGE }_{2}: 10.1\end{array}$ & $\mathrm{p}<0.007$ \\
\hline \multirow[t]{2}{*}{$\begin{array}{l}\text { Suffecool } \\
K[49]\end{array}$} & 2014 & 62 & $\begin{array}{l}\text { Double balloon (DB) } \\
\text { filling volume: } 80 \mathrm{ml} \\
\text { in situ time: } 12 \mathrm{~h}\end{array}$ & $12 \mathrm{~h}$ & $\begin{array}{l}\text { Induction to delivery time }(\mathrm{h}) \\
\mathrm{DB}: 19.1 \pm 5.0 \\
\mathrm{PGE}_{2}: 24.4 \pm 8.7\end{array}$ & $p=0.05$ \\
\hline & & & & & $\begin{array}{l}\text { Vaginal delivery rate in } 24 \mathrm{~h}(\%) \\
\text { DB: } 87.1 \\
\text { PGE }_{2}: 47.4\end{array}$ & $p=0.002$ \\
\hline
\end{tabular}

ley catheter in situ for 24 hours compared to $59.5 \%$ for Foley catheter in situ for 12 hours and $48.5 \%$ for $\mathrm{PGE}_{2}$ vaginal insert ( $p<0.001$ ), a clinically relevant finding. The results of the two randomised prospective comparative studies of double balloon catheter vs. $10 \mathrm{mg} \mathrm{PGE} 2$ vaginal insert (insertion time up to 24 hours) were in agreement, finding no significant difference in caesarean rate between the methods but a significantly greater need for oxytocin and lower rate of uterine hyperstimulation with the double balloon catheter without affecting neonatal outcome. Rate of vaginal deliveries in 24 hours differed between the two studies: While Cromi et al. 2012 [41] showed a significantly higher rate with the double balloon catheter (68.6 vs. $49.5 \%$ ), Du et al. 2014 [42] did not (50 vs. 53.2\%).

A recently published randomised trial in 62 nulliparae with unfavourable cervix (BS <6) compared the double balloon catheter (filling volume $80 \mathrm{ml}$, in situ for up to 12 hours, oxytocin intravenously 6 hours after catheter insertion) to a $10 \mathrm{mg} \mathrm{PGE}_{2}$ vaginal insert (insertion time up to 12 hours) [48]. Average induction to delivery time was significantly shorter for the double balloon catheter than for $\mathrm{PGE}_{2}$ vaginal insert (17.9 vs. 26.7 hours) and rate of vaginal deliveries in 24 hours was significantly higher ( 87.1 vs. $47.4 \%$ ) with similar caesarean rates (51.6 vs. $54.8 \%$ ) and no significant differences in neonatal outcome. Uterine hyperstimulation occurred at a rate of $25.8 \%$ with $\mathrm{PGE}_{2}$ vaginal insert compared to $0 \%$ for the double balloon catheter.

A shortened induction to birth interval is meaningful since it correlates closely with patient satisfaction with the method of induction [49].

\section{Balloon Catheter vs. Misoprostol}

\section{Balloon catheter vs. vaginal misoprostol}

Numerous studies have investigated the use of Foley catheters

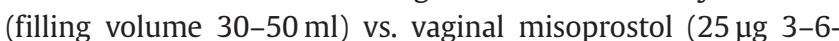
hourly). A recently published meta-analysis of 10 randomised studies conducted between 2001 and 2012 ( $n=1520)$ summarises the results [50]. More recently data from the 2014 PROBAAT-M study have been published [50] ( Table 6). 129 women (BS 0-5) were treated either with Foley catheters (filling volume $30 \mathrm{ml}$ ) or with vaginal misoprostol ( $25 \mu \mathrm{g}$ 4-hourly, maximum 3 doses/24 h); when the Bishop score was $\geq 6$ amniotomy was performed and intravenous oxytocin commenced with dosing according to the strength of contractions. The main findings of the PROBAAT-M study that differ with those of the meta-analysis are a longer induction to delivery time and a non-significantly raised incidence of uterine hyperstimulation for the Foley catheter. The authors offer no explanation for these findings. The findings of the meta-analysis are in general agreement with that of Fox et al. published in 2011 [33] ( 9 trials, $n=1603$ ), although 4 of these trials used $50 \mu \mathrm{g}$ vaginal misoprostol 4- to 6-hourly. Interestingly the average induction to delivery time between study groups did not differ significantly (Fox et al.) There was also no significant difference in the incidence of chorioamnionitis (RR 1.13; $95 \% \mathrm{CI}$ $0.61-2.09)$.

\section{Balloon catheter vs. oral misoprostol}

To date there are few trials comparing the Foley catheter to oral misoprostol for labour induction and patient numbers are small 
Table 6 Labour induction: Foley catheter vs. vaginal misoprostol.

\begin{tabular}{|c|c|c|c|}
\hline \multicolumn{4}{|c|}{ Meta-analysis 2014 ( 10 studies, $n=1520$ ) } \\
\hline \multirow[t]{3}{*}{ Significant findings } & Oxytocin for induction/augmentation of labour & \multicolumn{2}{|c|}{$\operatorname{RR}(95 \% \mathrm{Cl}) 1.74(1.30-2.32)$} \\
\hline & Uterine hyperstimulation & \multicolumn{2}{|c|}{$\operatorname{RR}(95 \% \mathrm{Cl}) 0.39(0.26-0.60)$} \\
\hline & Uterine hyperstimulation syndrome ${ }^{*}$ & \multicolumn{2}{|c|}{$\operatorname{RR}(95 \% \mathrm{Cl}) 0.39(0.24-0.61)$} \\
\hline No significant difference & \multicolumn{3}{|c|}{ Caesarean rate, postpartum haemorrhage, chorioamnionitis/endomyometritis, 5-minute Apgar < 7} \\
\hline PROBAAT-M Study ( $n=56$ ) & $25 \mu \mathrm{g}$ misoprostol $(n=64)$ & Foley catheter $(n=65)$ & p-value \\
\hline Caesarean section rate (\%) & 17 & 25 & 0.29 \\
\hline $\begin{array}{l}\text { Caesarean due to failure to progress } \\
\text { in the } 1 \text { st stage of labour (\%) }\end{array}$ & 3 & 14 & 0.03 \\
\hline Induction to delivery time (median, h) & 25 & 36 & $<0.001$ \\
\hline Oxytocin augmentation (\%) & 50 & 82 & $<0.001$ \\
\hline Uterine hyperstimulation (\%) & 2 & 4 & 0.59 \\
\hline Arterial umbilical cord $\mathrm{pH}<7.10(\%)$ & 9 & 10 & 1.00 \\
\hline
\end{tabular}

Jozwiak M et al. Am J Perinatol 2014; 31: 145 [50]

* uterine hyperstimulation (polysystole and/or prolonged uterine contraction) with pathological fetal heart rate

$[51,52]$. Advantages of oral misoprostol over the application vaginally - at similar dosage - are lower rates of uterine hyperstimulation, better neonatal outcome (5-minute Apgar < 7 [53]), better patient acceptance and lower infection risk through avoidance of vaginal manipulation.

There are currently two studies underway comparing the Foley catheter (filling volume $30 \mathrm{ml}$ ) with oral misoprostol $(50 \mu \mathrm{g} \mathrm{4-}$ hourly or $25 \mu \mathrm{g}$ 2-hourly). Primary endpoints of the first (PROBAAT-II Study [38]), which plans to include 1860 patients, are neonatal outcome (umbilical cord $\mathrm{pH} \leq 7.05$ or 5-minute Apgar $<7$ ) and postpartum haemorrhage (blood loss $\geq 1000 \mathrm{ml}$ ). The single primary endpoint of the second trial, with an intended study population of 620 women with preeclampsia, is vaginal delivery rate in 24 hours [39].

\section{Combined or Sequential Use of Balloon Catheters and other Uterine Stimulants $\nabla$}

Since balloon catheters cause cervical ripening but in the majority of cases not contractions, they have been combined with numerous other methods of uterine stimulation. The vaginal delivery rate in 24 hours was not increased by intravenous oxytocin commenced simultaneously with Foley catheter insertion during the 1 st stage of labour compared to Foley catheter alone (46 vs. $45 \%$ [54]). Also, there was no significant difference in median induction to delivery time between study groups receiving fixed vs. increasing doses of intravenous oxytocin following balloon insertion (23.7 vs. 19.2 hours) [55].

\section{Balloon Catheter Combined with Extra-amnionic Salt Infusion (EASI) \\ $\nabla$}

A comparative study of the Foley catheter plus extra-amniotic salt infusion vs. double balloon catheter alone showed significant advantages for the combined approach: The time between balloon insertion and expulsion was reduced as was induction to delivery time in the Foley catheter + salt infusion group [15]. A follow-on study by the same investigators [16] compared the Foley and double balloon catheters, both in combination with EASI. The results are summarised in Table 1. On comparison of the double balloon catheter with and without EASI, again significant advantages were found for the combined approach [56]: shorter balloon insertion to delivery time (14.2 vs. $20.45 \mathrm{~h}, \mathrm{p}<0.001)$ and a higher rate of balloon expulsion ( 68.5 vs. $51 \%, \mathrm{p}=0.04$ ).

\section{Balloon catheter and misoprostol simultaneously}

More recent randomised trials have focused on the combination of balloon catheter and misoprostol vs. misoprostol alone for labour induction. A 2012 Cochrane review [26] including 8 studies published before January $2012(n=1295)$ summarises this data. Findings were a significantly increased vaginal delivery rate in 24 hours (RR 0.45 ; 95\% CI 0.25-0.71) for the combination method without an effect on the caesarean section rate, as well as a reduced incidence of uterine hypersimulation (RR 0.59; 95\% CI $0.35-0.78$ ) for the combined method. Evidence on the incidence of the uterine hyperstimulation syndrome is however conflicting. Results of randomised studies since 2012 are shown in 0 Table 7. In their prospective, randomised trial Kehl et al. compared the double balloon catheter (in situ time up to 24 hours) plus oral misoprostol $50 \mu \mathrm{g}$ (repeated after 4 and 8 hours, increased to $100 \mu \mathrm{g}$ as required) to oral misoprostol alone in a study population of 122 women [57]. The primary outcome of the study was failure of induction, which was defined as no vaginal delivery within 48 hours. There were significantly fewer induction failures in the control group (9.3 vs. $21.7 \%, \mathrm{p}=0.07$ ) as well as a significantly shorter median induction to delivery time (15.3 vs. 20.8 hours). In 3 further randomised trials conducted in the past 2 years, the combination of Foley catheter plus vaginal misoprostol $(25 \mu \mathrm{g}$ 4-hourly) vs. vaginal misoprostol alone lead to significantly shorter induction to delivery times, a significant reduction in uterine hyperstimulation and meconium stained liquor and less need for oxytocin [58-60] compared to misoprostol alone. Vaginal misoprostol given 6 hours after Foley catheter insertion was more effective than vaginal misoprostol alone [61] ( $\$$ Table 7). Overall, the combination of balloon catheter and vaginal misoprostol results in a reduction of uterine hyperstimulation (with or without fetal heart rate changes), and no significant differences in chorioamnionitis rates or neonatal outcome when compared to misoprostol alone. However because of low case numbers and the heterogeneity of available trials, the evidence is still insufficient for a general recommendation of the combination approach for clinical practice.

\section{Balloon catheter and misoprostol sequentially}

Until recently no trial had studied the use of double balloon catheters with sequential oral misoprostol. A multicentre, random- 
Table 7 Balloon catheter plus misoprostol vs. misoprostol alone for labour induction with unfavourable cervix. Results of recent randomised, controlled trials.

\begin{tabular}{|c|c|c|c|c|}
\hline Author, year & $\begin{array}{l}\text { Number of } \\
\text { patients ( } \mathrm{n} \text { ) }\end{array}$ & Intervention & Control & Significant findings \\
\hline $\begin{array}{l}\text { Kehl et al. } \\
2011[57]\end{array}$ & 122 & $\begin{array}{l}\text { Double balloon catheter (up to } 24 \mathrm{~h} \text { ) } \\
+50 \mu \mathrm{g} \text { misoprostol p. o. (dose increase } \\
\text { to } 100 \mu \mathrm{g} \text { possible) }\end{array}$ & $\begin{array}{l}50 \mu \mathrm{g} \text { misoprostol p. } 0 . \\
\text { (dose increase to } \\
100 \mu \mathrm{g} \text { possible) }\end{array}$ & $\begin{array}{l}\text { Induction to delivery time (median): } \\
15.3 \text { vs. } 20.8 \text { hours } \\
\text { Induction failure: } 9.3 \text { vs. } 21.2 \%\end{array}$ \\
\hline $\begin{array}{l}\text { Ande et al. } \\
2012[61]\end{array}$ & 100 & $\begin{array}{l}\text { Foley catheter }+50 \mu \mathrm{g} \text { vaginal misoprostol } \\
\text { following catheter insertion }\end{array}$ & $\begin{array}{l}50 \mu \mathrm{g} \text { vaginal } \\
\text { misoprostol (6-hourly) }\end{array}$ & $\begin{array}{l}\text { Vaginal delivery rate in } 12 \text { hours: } 92.5 \text { vs. } 60 \% \\
\text { Caesarean section: } 20 \text { vs. } 40 \%\end{array}$ \\
\hline $\begin{array}{l}\text { Carbone et al. } \\
2013[58]\end{array}$ & 123 & $\begin{array}{l}\text { Foley catheter }+25 \mu \mathrm{g} \text { vaginal misoprostol } \\
\text { (4-hourly) }\end{array}$ & $\begin{array}{l}25 \mu \text { g vaginal } \\
\text { misoprostol (4-hourly) }\end{array}$ & $\begin{array}{l}\text { Induction to delivery time (median): } \\
15.3 \text { vs. } 18.3 \text { hours } \\
\text { Cervical dilatation rate (median): } \\
13.7 \text { vs. } 17.1 \text { hours }\end{array}$ \\
\hline $\begin{array}{l}\text { Ugwu et al. } \\
2013 \text { [59] }\end{array}$ & 150 & $\begin{array}{l}\text { Foley catheter }+25 \mu \mathrm{g} \text { vaginal misoprostol } \\
\text { (4-hourly) }\end{array}$ & $\begin{array}{l}25 \mu \mathrm{g} \text { vaginal } \\
\text { misoprostol or } \\
\text { Foley catheter alone }\end{array}$ & $\begin{array}{l}\text { 1st stage of labour approx. } 3 \text { hours shorter } \\
\text { Oxytocin: } 40 \text { vs. } 17.5 \text { vs. } 25.6 \%\end{array}$ \\
\hline $\begin{array}{l}\text { Lanka et al. } \\
2014 \text { [60] }\end{array}$ & 126 & $\begin{array}{l}\text { Foley catheter }+25 \mu \mathrm{g} \text { vaginal misoprostol } \\
\text { (4-hourly) }\end{array}$ & $\begin{array}{l}25 \mu \mathrm{g} \text { vaginal } \\
\text { misoprostol (4-hourly) }\end{array}$ & $\begin{array}{l}\text { Uterine hyperstimulation: } 7.9 \text { vs. } 39.7 \% \\
\text { Meconium stained liquor: } 6.3 \text { vs. } 27 \%\end{array}$ \\
\hline $\begin{array}{l}\text { Kehl et al. } \\
2015[62]\end{array}$ & 326 & $\begin{array}{l}\text { Double balloon catheter, after } 24 \mathrm{~h} \\
50 \mu \mathrm{g} \text { misoprostol p. o. ( } 100 \mu \mathrm{g} \text { possible) }\end{array}$ & $\begin{array}{l}50 \mu \mathrm{g} \text { misoprostol p. } 0 . \\
\text { (100 } \mathrm{\mu g} \text { possible) }\end{array}$ & $\begin{array}{l}\text { Induction to delivery time (median): } \\
32.4 \text { vs. } 22.5 \text { hours } \\
\text { Total misoprostol dose } 100 \text { vs. } 200 \mu g\end{array}$ \\
\hline
\end{tabular}

ised, controlled trial of 326 pregnant women with unfavourable cervix and various induction indications has now been published [62]. Induction was either with double balloon catheter (in situ time up to 12 hours) followed by oral misoprostol $50 \mu \mathrm{g} 24$ hours after catheter insertion (repeat doses after 4 and 8 hours with the possibility of increasing dose to $100 \mu \mathrm{g}$ after 24 hours), or oral misoprostol alone with the same dosing schedule. Primary endpoints were induction to delivery time and vaginal delivery rate in 48 hours. There was a non-significant difference in caesarean section rate (21.6 vs. $29.8 \%$ ). Independent of parity, the median induction to delivery time for the combination group was significantly longer than for oral misoprostol alone (32.4 hours vs. 22.5 hours; $\mathrm{p}=0.004$ ). However this difference was not statistically significant when comparing primiparae and multiparae. There were no significant differences in vaginal delivery rate in 48 hours (79.5 vs. $84.9 \%$ ) or need for oxytocin. The number of misoprostol applications was however significantly fewer, and the total misoprostol dose significantly lower in the combination group. The double balloon catheter alone lead to effective contractions in $23.3 \%$ of cases. Whether better results would be achieved by giving oral misoprostol immediately after catheter removal or not, remains to be studied.

\section{Comment on Current Guidelines}

According to WHO recommendations from 2011 [63] balloon catheters are recommended for labour induction and are approximately as efficient as vaginal prostaglandins ( $\mathrm{PGE}_{2}$, misoprostol) (moderate quality of evidence, strong recommendation). A combination of balloon catheter and oxytocin is recommended as an alternative when prostaglandins (including misoprostol) are not available or are contraindicated (low quality evidence, weak recommendation). The balloon catheter is also mentioned as an option for labour induction after previous caesarean section (no recommendation grade stated).

According to the 2008 RCOG guidelines (update 2014 [64]) balloon catheters should not be used routinely for labour induction with unfavourable cervix, and their use after previous caesarean section should be studied in clinical trials.
The 2009 ACOG guidelines [65] recommend the Foley catheter as a sensible and effective alternative to prostaglandins for cervical ripening/labour induction (grade A recommendation). Its use is mentioned an option for outpatient induction.

The 2013 Canadian guidelines (SOGC) [66] advocate the balloon catheter as an acceptable method of labour induction following previous caesarean section (I-B) and for outpatient induction (II-B), with the double balloon catheter as second-line option. The guidelines draw attention to the greater need for oxytocin when using balloon catheters as well as lower rates of uterine tachysystole without increased risk of maternal (chorioamnionitis, endometritis) or neonatal infections.

In Germany there are no recommendations or guidelines on this subject.

\section{Conclusion \\ $\nabla$}

Induction of labour using balloon catheters has experienced a renaissance in recent years and the method is now part of many international guidelines. The statistics presented in this paper confirm that, just as with the more established prostaglandins, labour can be successfully induced using balloon catheters. The pros and cons of the balloon catheter compared to prostaglandins are shown in $\bigcirc$ Table 8.

The two catheters available for use are the Foley catheter, which is cheaper, and the double balloon catheter, which has the advantage of being licensed for use in labour induction. Combining medical induction with the use of balloon catheters is a particularly interesting option that results of a number of trials currently underway are expected to provide more detailed information on in future.

\section{Conflict of Interest \\ $\nabla$}

Sven Kehl: Presentation fee and travel costs (COOK Medical). 
Table 8 Advantages and disadvantages of balloon catheters compared to prostaglandin $\mathrm{E}_{2} /$ misoprostol.

$\begin{array}{ll}\text { Pros } & \text { Cons } \\ \text { single application } & \text { greater need for oxytocin augmentation } \\ \text { - no uterine hyperstimulation } \rightarrow \text { less risk to the fetus } & \text { potentially increased infection risk compared to oral prostaglandin } \\ \text { - cheaper than prostaglandin } \mathrm{E}_{2} & \\ \text { - no need for special storage (e.g. cold chain) } & \end{array}$

* Jozwiak M et al. Cochrane Database Syst Rev 2012; 8: CD001233 [26]

\section{References}

1 Huisman CM, Jozwiak M, de Leeuw JW et al. Cervical ripening in the Netherlands: a survey. Obstet Gynecol Int 2013; 2013: 745159

2 AQUA-Institut für angewandte Qualitätsförderung und Forschung im Gesundheitswesen. Geburtshilfe, Qualitätsreport 2013. Online: https:// www.sqg.de/ergebnisse/leistungsbereiche/geburtshilfe.html; last access: 01.05 .2015

3 Rath W, Pecks U. Medikamentöse Geburtseinleitung. 2. vollst. aktualisierte Aufl. Bremen, London, Boston: Uni-Med; 2010

4 Rath W. Misoprostol zur Geburtseinleitung - eine aktuelle Übersicht. Frauenarzt 2014; 55: 346-353

5 Norman JE, Stock S. Intracervical Foley catheter for induction of labour. Lancet 2011; 378: 2054-2055

$6 \mathrm{Lim} C E, \mathrm{Ng} R W, X u \mathrm{~K}$. Non-hormonal methods for induction of labour. Curr Opin Obstet Gynecol 2013; 25: 441-447

7 Sciscione AC. Methods of cervical ripening and labour induction: mechanical. Clin Obstet Gynecol 2014; 57: 369-376

8 Wing DA, Lockwood CJ, Barss VA. Techniques for ripening the unfavorable cervix prior to induction. 2014. Online: www.uptodate.com; last access: 01.05.2015

9 Manabe Y, Manabe A, Takahashi A. F prostaglandin levels in amniotic fluid during balloon-induced cervical softening and labor at term. Prostaglandins 1982; 23: 247-256

$10 \mathrm{Lim} \mathrm{SY,} \mathrm{Kim} \mathrm{H,} \mathrm{Kim} \mathrm{CH} \mathrm{et} \mathrm{al.} \mathrm{The} \mathrm{effect} \mathrm{of} \mathrm{a} \mathrm{Foley} \mathrm{catheter} \mathrm{balloon} \mathrm{on}$ cervical ripening. J Obstet Gynaecol 2013; 33: 830-838

11 Smith JA. Balloon dilators for labour induction: a historical review. J Med Ethics Hist Med 2013; 6: 10-14

12 Pennell CE, Henderson JJ, O'Neill MJ et al. Induction of labour in nulliparous women with an unfavorable cervix: a randomized trial comparing double and single balloon catheters and $\mathrm{PGE}_{2}$ gel. BJOG 2009; 116: 1443-1452

13 Solt I, Ben-Harush S, Kaminsky S et al. A prospective randomized study comparing induction of labour with the foley catheter and the cervical ripening double catheter in nulliparous and multiparous women. AJOG 2008; 201 (Suppl. 1): S124

14 Salim R, Zafran N, Nachum Z et al. Single-balloon compared with double-balloon catheters for induction of labour. Obstet Gynecol 2011; 118: 79-86

15 Mei-Dan E, Walfisch A, Suarez-Easton S et al. Comparison of two mechanical devices for cervical ripening: a prospective quasi-randomized trial. J Matern Fetal Neonatal Med 2012; 25: 723-727

16 Mei-Dan E, Walfisch A, Valencia C et al. Making cervical ripening EASI: a prospective controlled comparison of single versus double balloon catheters. J Matern Fetal Neonatal Med 2014; 27: 1765-1770

17 Delaney S, Shaffer BL, Cheng YW et al. Labor induction with a foley balloon inflated to $30 \mathrm{ml}$ compared with $60 \mathrm{ml}$ : a randomized trial. Obstet Gynecol 2010; 115: 1239-1245

18 Levy R, Kanengiser B, Furman B et al. A randomized trial comparing a $30 \mathrm{ml}$ and a $80 \mathrm{ml}$ Foley catheter balloon for preinduction cervical ripening. AJOG 2004; 191: 1632-1636

19 Kashanian M, Akbarian AR, Fekrat M. Cervical ripening and induction of labour with intravaginal misoprostol and foley catheter cervical traction. Int J Gynecol Obstet 2006; 92: 79-80

20 Berndl A, El-Chaar D, Murphy K et al. Does cervical ripening at term using a high volume foley catheter result in a lower caesarean section rate than a low volume foley catheter? A systematic review and metaanalysis. J Obstet Gynaecol Can 2014; 36: 678-687
21 Lutgendorf MA, Johnson A, Terpstra ER et al. Extra-amniotic balloon for preinduction cervical ripening: a randomized comparison of weighted traction versus unweighted. J Matern Fetal Neonatal Med 2012; 25: 581-586

22 MacKeen AD, Walker LT, Ruhstaller K et al. Foley catheter vs. prostaglandin as ripening agent in pregnant women with premature rupture of membranes. Am Osteopath Assoc 2014; 114: 686-692

23 Cabrerea IB, Quinones JN, Durie DE et al. Intracervical balloon placement and the risk of chorioamnionitis in term rupture of membranes. Obstet Gynecol 2014; 123 (Suppl.): S43

24 FOLCROM Trial: Foley Catheter in Rupture of Membranes. Online: https://mytomorrows.com/program/folcrom-trial-foley-catheter-inrupture-of-membranes; http://clinicaltrials.gov/ct2/show/ NCT01973036; last access: 01.05.2015

25 Heinemann J, Gillen G, Sanchez-Ramos L et al. Do mechanical methods of cervical ripening increase infectious morbidity? A systematic review. AJOG 2008; 199: 177-187

26 Jozwiak M, Bloemenkamp KW, Kelly AJ et al. Mechanical methods for induction of labour. Cochrane Database Syst Rev 2012; 3: CD001233

27 van Halem K, Bakker JHJ, Verhoeven CJ et al. Does use of an intrauterine catheter during labour increase risk of infection? J Matern Fetal Neonatal Med 2012; 25: 415-418

28 Jozwiak M, Oude Rengerink KO, Benthem $M$ et al. Foley catheter versus vaginal prostaglandin $E_{2}$ gel for induction of labour at term (PROBAAT trial): an open-label randomised controlled trial. Lancet 2011; 378: 2095-2103

29 Rouse DJ, Weiner SJ, Bloom SL et al. Failed labor induction. Obstet Gynecol 2011; 117: 267-272

30 Talaulikar VS, Arulkamaran S. Failed induction of labor: strategies to improve the success rate. Obstet Gynecol Surv 2011; 66: 717-728

31 Mazhar SB, Jabeen K. Outcome of mechanical mode of induction in failed primary labour induction. J Coll Physicians Surg Pak 2005; 15 : 616-619

32 Caliskan E, Dilbaz I, Gelisen O et al. Unsucessful labour induction in women with unfavourable cervical scores: predictors and management. Austr NZJ Obstet Gynecol 2004; 44: 262-267

33 Fox NS, Saltzman DH, Roman AS et al. Intravaginal misoprostol versus Foley catheter for labour induction: a meta-analysis. BJOG 2011; 118 : 647-654

34 Mozurkewich EL, Chilimigras JL, Berman DB et al. Methods of induction of labour: a systematic review. BMC Pregnancy Childbirth 2011; 11: 84-103

35 Shechter-Maor G, Haran G, Sadeh-Mestechkin D et al. Intravaginal prostaglandin E2 versus double-balloon catheter for labor induction in term oligohydramnios. J Perinat 2014; DOI: 10.1038/jp.2014.173

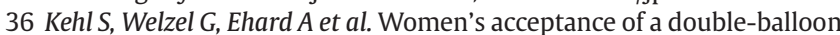
device as an additional method for inducing labour. Eur J Obstet Gynecol Reprod Biol 2013; 168: 30-35

37 Anabusi S, Mei-Dan E, Hallak M et al. Mechanical labor induction in the obese population: a secondary analysis of a prospective randomized trial. Arch Gynecol Obstet 2015; DOI: 10.1007/s00404-015-3765-3

38 ten Eikelder ML, Neervoort F, Oude Rengerink K et al. Induction of labour with a Foley catheter or oral misoprostol at term: the PROBAAT-II study, a multicentre randomised controlled trial. BMC Pregnancy Childbirth 2013; 13: 67-73

39 Bracken H, Mundle S, Faragher B et al. Induction of labour in pre-eclamptic women: a randomized trial comparing the Foley balloon catheter with oral misoprostol. BMC Pregnancy Childbirth 2014; 14: 308313 
40 Jonsson $M$, Hellgren $C$, Wiberg-Itzel $E$ et al. Assessment of pain in women randomly allocated to speculum or digital insertion of the Foley catheter for induction of labor. Acta Obstet Gynecol Scand 2011; 90: 997-1004

41 Cromi A, Ghezzi F, Uccella $S$ et al. A randomized trial of preinduction cervical ripening: dinoprostone vaginale insert versus double-balloon catheter. AJOG 2012; 207: 125e1-125e7

42 Du C, Liu Y, Liu Yet al. Double-balloon catheter vs. dinoprostone vaginal insert for induction of labor with an unfavorable cervix. Arch Gynecol Obstet 2014; DOI: 10.1007/s00404-014-3547-3

43 Vaknin Z, Kurzweil Y, Sherman D. Foley catheter balloon vs. locally applied prostaglandins for cervical ripening and labor induction: a systematic review and metaanalysis. Am J Obstet Gynecol 2010; 203: 418-429

44 Prager $M$, Grimfors-Eneroth E, Edlund $M$ et al. A randomized controlled trial of intravaginal dinoprostone, intravaginal misoprostol and transcervical balloon catheter for labour induction. BJOG 2008; 115: $1443-$ 1450

45 Hendersson JJ, Pennell CE, Dickinson JE. Transcervical Foley catheter should be used in preference to intravaginal prostaglandins for induction of labor with an unfavourable cervix. AJOG 2011; 205: e19-e20

46 van Baaren GJ, Jozwiak M, Opmeer B et al. Cost-effectiveness of induction of labour at term with a Foley catheter compared to vaginal prostaglandin E2 gel (PROBAAT trial). BJOG 2013; 120: 987-995

47 Cromi A, Ghezzi F, Agosti $M$ et al. Is transcervical Foley catheter actually slower than prostaglandins in ripening the cervix? A randomized study. AJOG 2011; 204: 338e1-338e7

48 Suffecool K, Rosenn BM, Kam S et al. Labor induction in nulliparous women with an unfavorable cervix: double-balloon catheter versus dinoprostone. J Perinat Med 2014; 42: 213-218

49 Gibbins J, Thomson AM. Women's expectations and experiences of childbirth. Midwifes 2001; 17: 302-313

50 Jozwiak $M$, ten Eikelder $M$, Rengerink $K O$ et al. Foley catheter versus vaginal misoprostol: randomized controlled trial (PROBAAT-M Study) and systematic review and meta-analysis of literature. Am J Perinatol 2014; 31: 145-156

51 Abramovici D, Goldwasser S, Mabie BC et al. A randomized comparison of oral misoprostol versus Foley catheter and oxytocin for induction of labor at term. AJOG 1999; 181: 1108-1112

52 Sheikher C, Suri N, Khali U. Comparative evaluation of oral misoprostol, vaginal misoprostol and intracervical Foley's catheter for induction of labour at term. JK Science 2009; 11: 75-77
53 Alfirevic Z, Aflaifel N, Weeks A. Oral misoprostol for induction of labour. Cochrane Database Syst Rev 2014; 6: CD001338

54 Pettker CM, Pocock SB, Smok DP et al. Transcervical Foley catheter with and without oxytocin for cervical ripening: a randomized controlled trial. Obstet Gynecol 2008; 111: 1320-1326

55 Fitzpatrick CB, Grotegut C, Bishop TS et al. Cervical ripening with foley balloon plus fixed versus incremental low-dose oxytocin: a randomized controlled trial. J Matern Fetal Neonatal Med 2012; 25: 10061010

56 Walfisch A, Mei-Dan E, Hallak M. Trans-cervical double balloon catheter with and without extra-amniotic saline infusion for cervical ripening: a prospective quasi-randomized trial. J Matern Fetal Neonatal Med 2015; 28: 846-853

57 Kehl S, Ehard A, Berlit S et al. Combination of misoprostol and mechanical dilatation for induction of labour: a randomized controlled trial. Eur J Obstet Gynecol Reprod Biol 2011; 159: 315-319

58 Carbone JF, Tuuli MG, Fogerty PJ et al. Combination of Foley balloon and vaginal misoprostol compared with vaginal misoprostol alone for cervical ripening and labor induction - a randomized controlled trial. Obstet Gynecol 2013; 121: 247-252

59 Ugwu EO, Onah HE, Obi SN et al. Effect of the Foley catheter and synchronous low dose misoprostol administration on cervical ripening: a randomised controlled trial. J Obstet Gynaecol 2013; 33: 572-577

60 Lanka S, Surapaneni T, Nirmalan PK. Concurrent use of Foley catheter and misoprostol for induction of labor: a randomized clinical trial of efficacy and safety. Obstet Gynaecol Res 2014; 40: 1527-1533

61 Ande $A B$, Ezeanochie CM, Olagbuji NB. Induction of labor prolonged pregnancy with unfavorable cervix: comparison of sequential intracervical Foley catheter-intravaginal misoprostol and intravaginal misoprostol alone. Arch Gynecol Obstet 2012; 285: 967-971

62 Kehl S, Ziegler J, Schleussner E et al. Sequential use of double-balloon catheter and oral misoprostol versus oral misoprostol alone for induction of labour at term (CRBplus trial): a multicentre, open-label randomised controlled trial. BJOG 2015; 122: 129-136

63 WHO recommendations for induction of labour. Online: http:// whqlibdoc.who.int.hg/2011; last access: 01.05.2015

64 Royal College of Obstetricians and Gynaecologists. Induction of labour 2008 (update 2013). NICE Clinical Guideline 70. Online: www.nice. org.uk/guidance/cg70; last access: 01.05.2015

65 ACOG Committee on Practice Bulletins - Obstetrics. ACOG Practice Bulletin No. 107: Induction of labour. Obstet Gynecol 2009; 114 (2 Pt 1): 386-397

66 Leduc D, Biringer A, Lee L et al. SOGC Clinical Practice Guideline No. 296. Induction of Labour. J Obstet Gynaecol Can 2013; 35: S1-S17 